\title{
Employer of Last Resort as a New “New Deal": A few thoughts on Turkey
}

\author{
ILKER ASLAN"
Université de Lausanne
ilkaslan@icloud.com
}

\begin{abstract}
Modern Monetary Theory emerges as a plausible alternative to solve Turkey's staggering unemployment problem. This proposed solution here is the introduction of job guarantee program, which produces a non-discretionary automatic stabilizer that fosters both price stability and full employment. As a monetary sovereign, Turkey has the capacity to use deficit spending to bring growth and provide full employment to the millions who are in involuntary unemployment. The goal here is to tame the business cycles without throwing millions into unemployment, which has social and economic ramifications. In the absence of job creation by the private sector, this can be achieved through the use of government, providing job guarantees and the state acting as an employer of last resort by creating public projects, which will be cyclically adjusted in order to achieve full employment.
\end{abstract}

"The conservative belief that there is some law of nature, which prevents men from being employed, and that it is "rash" to employ men, and it is financially "sound" to maintain a tenth of the population in idleness for an indefinite period, is crazily improbable-the sort of thing which no man could believe who had not hid head fuddled with nonsense for years and years. We shall try to show him that if new forms of employment are offered, more men will be employed, that to set unemployed men to work on useful tasks does what it appears to do, namely, increases the national wealth; that the notion that we shall, for intricate reasons, ruin ourselves financially if we use this means to increase our well-being, is what it looks like-a bogy."

John Maynard Keynes, "Essays in Persuasion," The Collected Writings of John Maynard Keynes, vol. 9, Donald Moggridge, ed., (London and Basingstoke: Macmillan/St. Martin's Press, 1972), pp. 90-92

*Thanks to Dr. Dirk Ehnts and two anonymous referees, who have commented on different versions of this paper for their helpful comments. All possible errors and omissions in this manuscript are my own.

\section{INTRODUCTION}

$\mathrm{D}$ ue to the COVID-19 pandemic, unemployment has re-emerged as a hot topic around the world. In 1995, it was estimated that there were 800 million unemployed (Bora and Erdogan, 2017). In early 2000s, this number has surpassed one billion. As the paper was being drafted, the COVID-19 virus has hit the world with full force. Industries as a whole have begun to shut down with mounting job losses. Unless drastic and decisive measures are taken, we can very likely see the unemployment rates as high as the Great Depression levels in 1930s around the world. The unemployment increased due to the culmination of interrelated factors: pandemic-related business interruptions, fall in consumer demand, and increasing uncertainty around the future of the global economy. In the political spectrum, the political parties pay a lip service to alleviate unemployment and promise solutions that only put band-aid to the problem, as opposed to finding a permanent and sustainable answer to bring a complete end to involuntary unemployment. According to conventional thinking, "full employment" is neither considered a socio-political ideal nor does it remain as a realistic and attainable goal (Bora and Erdogan, 2017). To the contrary, the existence of unemployment is considered normal (in fact, desirable, from a theoretical perspective). It is an individual problem rather than the result of a systemic failure of the economic system to 
provide an adequate amount of jobs. This can best be described by the common economic definitions. One is the Phillips curve, which posits an inverse correlation between price stability and unemployment. A portion of the labor force remaining unemployed is acceptable, in fact, desired for the sake of taming inflation and maintaining price stability. Second is the NAIRU (NonAccelerating Inflation Rate of Unemployment). This is a benchmark rate for the governments to decide when they should accelerate or decelerate economic growth. If the policy makers come to the conclusion that there are few unemployed in the economy (that is, too many people have jobs), it increases interest rates in order to reduce the purchasing power with the explicit aim of increasing unemployment; therefore, eliminate any inflationary pressures due to the fact that too many people have jobs and disposable income to spend. NAIRU denotes the specific level of unemployment that is evident in an economy that does not cause inflation to increase, hence, with bit of an irony, is considered as the "natural" rate of unemployment. Here, the government chooses an explicit policy to retain a certain percentage of the population in involuntary unemployment ${ }^{1}$

When we look at the brief recent economic history of Turkey, we see that it has been mired with waves of optimism and pessimism for the past four decades, since it adopted the economic liberalization program on Jan 24th, 1980, and had gained speed since 1990s, when Turkey embraced the Washington Consensus, a standard package prescribed by the IMF and World Bank to crisis-struck economies as a prescription to stabilize the economy and open up the economy to trade and investment. One problem always remained: Regardless of the changes in the GDP, inflation, import/export balance, Turkey has always suffered from high and chronic involuntary unemployment.

When we look at the recent history of Turkey, we can see this trend even more starkly. From 2001 until 2013, Turkey was proclaimed to be the poster child of market liberalization policies and IMF austerity. Dwindling exports and rapidly depreciating currency resulted in increasing poverty rates and unemployment. During the heydays of economic liberalization, the current AKP government sowed the political credit and PR dividends of the IMF policies instigated by the previous tripartitecoalition government adopted in the aftermath of the 2001 crisis, especially during the periods of abundant and cheap liquidity throughout the global market. GDP

\footnotetext{
${ }^{1}$ In The End of Work, Rifkin (2007) notes that the increase in unemployment is an irreversible process, where he argues that the underlying structural factor is that the economic growth no longer results in an increase in employment, but in fact has the opposite effect and leads to further unemployment. Increasing automatization, introduction of new technologies and precariatization of the labor are the main factors behind this phenomenon (cf. Negt, 2010).
}

grew, and the Turkish Lira remained relatively stable between 2002 until 2013. The era was subsequently followed by the Gezi Park protests in 2013, which culminated in increasing authoritarianism in the governance while gradually weakening the institutional check and balances. This has caused two issues on the economic front: foreign and domestic investors are put off by the arbitrary, and increasingly nepotistic economic decisions by the government, exemplified by giving preferential tax breaks and awarding government contracts to conglomerates friendly to AKP. Investor confidence has weaned, and the Lira depreciated from 1.20 TRY to 1 USD in 2002 since the ruling AKP has come to power to 8.50 TRY in August 2021, and this trend is likely to continue. The government based its strategy to attract FDI and international borrowing: As the confidence in the economy waned and the job creation by the private sector stalled, the issue of unemployment has come to the forefront of economic challenges.

On one hand, the labor participation is only 53\% ( $71.9 \%$ for men, $34.6 \%$ for women). On the other hand, even with today's official unemployment rate at $14.3 \%$, there are over 4.5 million who are unemployed, millions more who are involuntarily working below minimum and poverty wages, and an estimated eight million who are officially described as out of the labor force but would be willing to work if a suitable chance exists.

Our goal is to introduce the "Employer as a Last Resort" (ELR) scheme as a job guarantee (JG) program in Turkey. By doing so, my point of reference will be to base it on the foundations of the Modern Monetary Theory (MMT). While this paper uses Turkey as an example, the arguments presented here can be used on any monetary sovereign country, where the government is the monopoly issue of the fiat currency ${ }^{2}$ We will first briefly explain the theory behind this proposal. Secondly, we will then assess the suitability of ELR and address the challenges in Turkey. Third, we outline a few program ideas for an initial start to the ELR programs in Turkey. Fourth, we will address the question of financing of the program.

\footnotetext{
${ }^{2}$ I must add here that there is a wide range of monetary sovereignty in the world. For instance, countries such as Switzerland, Norway, Canada, the US, the UK, Japan can borrow, spend and tax in their own currencies. In contrast; Greece, Italy and Spain do not have monetary sovereignty because they have transferred their currencyissuing authority to the European Central Bank. Turkey, Russia, Ukraine, and Argentina issue their own currencies but they also borrow heavily in USD and EUR, which tarnishes their monetary sovereignty (cf. Wray, 1998; Kelton, 2020).
} 


\section{Theory Behind the ELR AS A Job GuARANTEe}

The departure point of the ELR comes from Keynes' General Theory, where he advocated for the maintenance of full employment in the long run by taking the job offers to the unemployed workers and distressed areas in a targeted fashion (Keynes, 1936). Keynes considered an acceptable full employment level at any phase of the business cycle (recession or expansion) as an unemployment rate below one percent (ibid; Tcherneva, 2012). Keynes's policy writings in the interwar period gives us a blueprint to a Keynesian Plan for full employment, even though he has never specifically drafted such a program. According to Keynes, the main purpose of the economic policy was to solve the "'real problem, fundamental yet essentially simple . . . [namely] to provide employment to everyone" (Keynes, 1980). His argument was that every person who is unemployed puts another one out of work due to losses in purchasing power (Tcherneva, 2012). Kregel (2008) also noted that anyone who has taken the trouble to attempt to understand The General Theory should recognize his theory could be and was applied to the conditions outside of depression. Minsky (1986) took up Keynes's "on-the-spot employment" and argued for a proposal for the government to act as an employer of last resort to achieve the long-run full employment objective.

Elimination of widespread and persistent unemployment is a critical theme for the present and future, given that continuous technological advancements can lead to permanent technological unemployment, as jobs and skillsets in various sectors would be drastically reduced or become obsolete by the advance of artificial intelligence and machine learning. Here, the public sector would have the ability to use non-utilized labor whose employment has been displaced due to technological advancement in a labor intensive productive activity in education, public welfare, and health. Even though this would be "inefficient" for the private firm, it is reasonable from the perspective of social well-being for the sake of reducing unemployment (Forstater, 2002; Lowe, 1988). Unless the issue to tackle permanent unemployment remains unchecked, the efforts to reduce poverty and generation of economic security for the public will falter ${ }^{3}$

At the heart of this proposal lies the principle of effective demand, which proposes that macroeconomic policy needs to be directed to achieve several key objectives to sustain the point of effectiveness at a level consistent with full employment, and in order

\footnotetext{
${ }^{3}$ For an extensive analysis on the importance of full employment, see Pasinetti (1993)
}

to obtain these objectives, a structural change in the role of government is required (Rogers, 2010). In other words, unemployment is not a consequence of deficient aggregate demand in the economy, but due to deficient effective demand as well as technological and structural changes in the economy. Giving a lift to the aggregate demand or fighting against the tides of technological advancements are not sufficient to achieve full employment in the economy. This can only be fully alleviated by direct job creation in the public sector, where private sector is insufficient of absorbing the unemployed labor, and the ELR approach argues that the government bears this responsibility to fulfil this role. Forstater (2002) argues that " $t$ he public service employment approach acknowledges the unlikelihood of attaining full employment through indirect means such as stimulating private sector demand while identifying a number of clear advantages to public employment programs. This is because "the public investors are not hampered by uncertainties about future demand, because they themselves determine the purpose that investment and its final output is to serve, for instance, the items that make up the infrastructure." (Lowe, 1988: 107). ELR proposal more closely resembles what Keynes himself had in mind than what today passes for Keynesian policy (Tcherneva, 2008). The approach of Keynes was that the policy makers had a duty to ensure that "everything that could humanly done by the government" (Keynes, 1980). The mainstream approach to stimulate employment is conducted by using general tax cuts or spending-increases tends to favor the already relatively well-off in the hope that jobs will "trickle down" to the unemployed and poor. The JG/ELR program directly targets the unemployed to lift them out of poverty (Wray, 2012).

Minsky expounded upon the Keynesian theory of maintaining effective demand and proposed the ELR as a job guarantee program. His was a permanent plan for direct job creation, geared toward employing those who are left at the margins of the labor market and cannot find gainful employment. A paid employment is provided and guaranteed to all those who are willing to work at a specified wage on a variety of public works programs offered by the government. The ELR is conceived to be flexible in order to provide jobs in distressed areas, which have not been able to collect the fruits of an economic boom even in times of expansion, and continue to be more vulnerable for social and economic malaises during depressions. The public works programs are undertaken continuously to ensure that full employment is achieved when the economy is expanding and contracting during the economic cycles. Most importantly, the job losses are not tolerated as a trade-off for the sake of maintaining price stability and 
taming the inflation as it is depicted in Phillips curve. Vickrey (2004) notes that finding a way of controlling inflation that does not involve unemployment is of vital importance in order to ensure that steps against unemployment would not be inhibited by fear of inflation. It rests on a flexible component, which absorbs the employed from private enterprise in downturns as well as a permanent component, which represents a considerable socialization of investment for stability.

From a theoretical view, Minsky had gone a step further to reinterpret the Keynesian theory of effective demand and approach to the theory of full employment. According to Minsky, demand should be created for all who are willing to work as opposed to those who are likely to be considered "employable" by the private sector. (Minsky, 1986). This continuous cycle of demand for labor could be maintained through a job guarantee program with the government acting as the employer of last resort, creating guaranteed jobs via public works. The spread and intensity of the public works would also be adjusted in order to facilitate the larger socialization of investment, where the public investment is geared toward social purposes with the active involvement of the government instead of shying away from any being an active economic factor as the proponents of neoclassical/neoliberal school argues. The idea of unemployment has ceased to be a burning policy issue with the advent of free market ideology, where the existence of some unemployment in the economy is not only tolerated, but actually desired in order to tame the inflation.

MMT follows the footsteps of Minsky and Keynes. It challenges the notion that government deficits are, by and large, good and necessary for the economy because government budgets do not act like household or private businesses because the government is the monopoly issue of the fiat currency, and it can create as much money as needed in order to provide full employment. As opposed to chasing the goal of a balanced budget in the economy, we should be chasing the goal of a balanced economy where involuntary unemployment is fully eradicated through job guarantee and ELR programs. MMT focuses on this point: creating full employment and building a better economy is not dependent on raising enough revenue by taxation or borrowing. Once we accept that deficits are not, by definition, bad and they are beneficial for the economy, we can and should prioritize public interests to the fore.

There are a few key design features of an ELR program, which have been outlined in the works of post-Keynesian and Modern Monetary Theory economists (Tcherneva, 2008, 2018, 2020; Mitchell and Muysken, 2008; Wray, 1998 and 2012; Forstater, 1999; Ehnts and Höfgen, 2019). Tcherneva (2008, 2018, 2020) had made an extensive list of the ELR features, which can be used as a blueprint for implementation worldwide.

\section{a. Unconditional job offers}

A job is guaranteed to be available to all who are unemployed, ready, and willing to work. Its principal goal is to be an inclusive program for all who volunteer to work. There are no set preconditions in order to qualify for a job. Any willing and able person of legal working age, irrespective of their background (sex, color, creed, race, etc), can participate. The job guarantee would neither be provided as a replacement for essential government services and public works nor are they provisioned to be charitable project sponsored by the government. It does not remove the benefits received by the unemployed unless they participate in the ELR program. Conversely, it reduces the welfare expenditures by the government and makes them unnecessary since the job guarantee provides a living-income floor.

\section{b. Avoid competition with the private sector}

The jobs as part of ELR are not to be construed as cannibalizing on the potential labor of the private sector because the program would be employing people who are not able to find employment anywhere in the economy. The ELR jobs would not act as the employer of first and only resort as it had done in the command economies, but it would be the employer of last resort. The ELR program would operate within market conditions and function to private sector employment in complement. If the private sector is stronger to reduce the unemployment, the size of the ELR program would be subsequently smaller. The majority of the employment will rest in the private sector and continue to be primary driver for the employment growth.

There have been criticisms that such public-funded employment programs would crowd out the disposable labor away from the private sector (Wray, 1998). Given that the private sector will never produce and maintain (and has never provided) continuous full employment and the government cannot force the firms to hire labor which they deem to be unnecessary, public sector is the only venue in which an employment guarantee can be provided. The private firms in the economy hire on a pro-cyclical basis, that is, when the economy is performing well, they hire more labor and vice versa. The ELR works counter-cyclically, hence more ELR jobs would be created when the economy is performing poorly in order to reduce the labor who is able and willing to work but cannot find the vacancies. It is a 
complementary, not a substitute, for private and public sector employment.

\section{c. Delivered by social economy and not-for-profit sector}

The ELR programs are created in sectors with a social purpose and operate as non-profits (i.e., food banks, public health centers, community centers, retirement homes, orphanages, etc.) These places continuously look for employees looking for help, and they would be hiring people with government funding.

ELR puts social and economic justice at the heart of the program. It separates the offer of employment from the profitability of employment (Tcherneva, 2008; 2018). The ELR projects are created to serve community needs, rather than prioritizing whether the projects are deemed "profitable" in the narrow sense. It can be constructed to address the care and environmental needs across Turkey, which can provide on-demand jobs which serve the public goods with a social purpose and without a profit motive. The program can prioritize disaster prevention and relief, community renewal, food relief in addition to supporting arts initiatives, youth apprenticeships, reintegration programs for ex-inmates, at-risk youth as well as special needs programs for childcare and elderly care. As a transitional program, it serves as a stepping stone to paid work-from unemployment to employment or from JG employment to other forms of private, public, and nonprofit employment.

\section{d. Adds to and does not subtract from existing programs}

These ELR programs would be complementing and not be replacing any existing government programs. This means that they are not a substitute to unemployment insurance, low-income assistance, social security, etc. It would not displace existing program. For instance, the people would still have the option to choose between receiving unemployment insurance or participating in the ELR program. If they choose to receive unemployment benefits but cannot find employment opportunities within the private or public sector by the time their unemployment benefits are exhausted, they would still be able to participate in the ELR program.

Given that the program offers are open to all and the participants would be compensated decently for their work, it will not only be an appealing alternative to welfare policies, but will also reduce the need for utilizing such programs.

e. Good working conditions: living wage, flexible hours, vacation, educational opportunities
The ELR programs offer living wage with flexible hours and all the pertinent social benefits (i.e., unemployment insurance, holidays, etc.). The ELR jobs include every benefit a real job would offer and the participants should consider them as "real jobs."

It offers a wage-benefit package, establishing a floor to living incomes. The wage in this proposal is TRY 12,000 per month plus benefits (roughly amounts to EUR 1200 per month in August 2021 rates). This figure is taken in order to ensure that the wage level is comparable to the cost of living in Turkey. The wages should be set high enough in order to incentivize participation in the program: Participants actually receive a decent wage for their efforts and not receive a pittance for their labor. It should pay a living wage and not tied to any other anti-poverty program. It also does not require people to work in order to qualify for their benefits. When a person chooses to take up employment in a ELR role, they will no longer collect any benefits on unemployment insurance or welfare assistance. This will not only reduce spending by the government on these programs, but given that the participants are engaged taxable gainful employment, the multiplier effect of their disposable income and spending will boost the economic activity and state revenues. This will break the vicious cycle of unemployment at the bottom ranks of the income distribution and discrimination in the labor market. In short, anyone who wants a job at a decent pay will be guaranteed to have it.

\section{$f$. Funded by national level sovereign}

The ELR programs are not to be funded at the local, municipal, or regional government level. The funding happens at the sovereign level, where the national bank is located and the program is underwritten by the central government and not reliant on the local funding of the regional or municipal government. Unemployment behaves like an epidemic, developing rapidly and unexpectedly and spreading with the distinct pattern of a contagion effect. Simultaneously, it inflicts large social and human costs (Tcherneva 2017).

Therefore, the proposed funding mechanism here is, in part, modeled after disaster and emergency relief in the United States (cf. Wray, 1998; Tcherneva 2018). For example, each year Parliament would pass base appropriations for the management of the ELR program for the given year. Given that the actual level of unemployment over a given year is unknown-as in small- and large-scale disasters-the funding would have to vary depending on the need. This can either be achieved by allowing for discretionary spending in the annual state budget or authorizing annual increases in the ELR funding which would not be subject to budgetary controls or caps. In the following year, a 
rolling average would be used to accommodate for the actual funding. If the private sector employment is higher over the course of several years, the ELR budget can be lowered as a result. Given the only central Turkish government has to monetary means to design a countercyclical budget to address the changes in unemployment, it will be funded on the state level, but it will be up to the local city and municipal governments to locally implement the programs.

The goal here is to ensure that jobs can be offered on demand in times of economic expansions and recessions so that the ELR program could operate as a macroeconomic countercyclical stabilizer ${ }^{4}$

\section{The Need for ELR in TurkeY: Suitability ANd Challenges}

Since 1930s, a number of countries have returned to the idea of a government program to operate as "employer of last resort" (ELR) in order to eliminate the issue of widespread unemployment. Papadimitriou (2012) noted that "[s]uch direct public-service job creation programs by governments, including developing countries, have had long-term positive results: throughout the century, the United States, Sweden, India, South Africa, Argentina, Ethiopia, South Korea, [. . .], Chile, among others, have intermittently adopted policies that made them 'employers of last resort' - a term coined by economist Hyman Minsky in the 1960s—when private sector demand was not sufficient. South Korea, for example, during the meltdown of 1997-98, implemented a master plan for tackling unemployment that accounted for $10 \%$ of government expenditure. It employed workers on public projects that included cultivating forests, building small public facilities, repairing public utilities, environmental clean-up work, staffing community and welfare centers, and information/technology-related projects targeted at the young and computer-literate. The overall economy expanded and thrived in the aftermath."

The idea is not new and has been implemented suc-

\footnotetext{
${ }^{4}$ Tcherneva (2018) argues that "[I]t is also important to point out that government programs cannot be 'prefunded' via tax collections. Program budgets are appropriated ahead of time, allowing the necessary spending to take place. Tax collections are a reflux, after the spending has occurred, and the amount of taxes collected varies with the health of the economy and in precisely the opposite direction to the needs of the program. In recessions the JG requires increased funding, exactly at a time when tax revenues decline. So raising taxes to prefund the program is not only impossible, but trying to do so will be counterproductive- the income that the government provides to the unemployed needs to be a net injection in the economy, not offset by taking away income somewhere else in the economy. The task is to allow the budget to float. Since the program always spends neither more nor less than what is needed to hire all people who are in need of a job, spending is, in a sense, at the "right" level because it responds to the needs of the economy."
}

cessfully in various countries around the world. In the US, for instance, the Work Project Administration (WPA) and the Civil Conservation Corps were established in the 1930s. The right to a decent good paying job sufficient to live was enshrined in the Economic Bill of Rights (1944) and targets for a maximum economic growth were established to achieve a maximal employment rate with the introduction of Employment Act (1946). These acts were passed not only with the goal of eliminating unemployment, but also as a means of distributional equity to reduce the income inequality which creates social problems and alienation. My argument is that full employment could and should be achieved in Turkey by the introduction of a job guarantee program where the government acts as an ELR in the spirit of a 1930s New Deal program in Turkey. An introduction of an ELR program as an "on-the-spot" program will, in fact, act as a macroeconomic stabilizer, which will put a floor on the wages and eliminate the social and economic costs of unemployment, such as poverty, malnutrition, poor prenatal care, drug addiction, and crime (Ehnts and Höfgen, 2019).

For the past four decades, the main goals of Turkish economic policy-making have been geared toward taming the inflation, maintain GDP growth by attracting foreign direct investment, and maintain currency stability, which had been attained with dubious results. Nonetheless, the reduction of high unemployment had not been in the forefront of the successive governments. A whopping $58 \%$ of working age adults in Turkey above the age of fifteen are not in gainful employment. Female unemployment is at $45.3 \%$, 5 and female labor participation is abysmally low at $25.3 \%$ per March 2020. An additional challenge is the increasing precariousness in the labor market. $46 \%$ of the labor force works at minimum wage level, which amount to TRY 2,825 per month (USD 331 per August 2021 FX rate). At the same time, the overall unemployment rate in EU-27 remains at $7.1 \%$ in June 2021, even after having taken the brunt of the pandemic. At least $40 \%$ of those in the labor force work only at minimum wage ${ }^{6}$ More than $60 \%$ of Turks live below the poverty line, of which 16.5 million ( $20 \%$ of the population) live below the subsistence level and under the risk of malnutrition.7 As per August 2021, the official unemployment rate in Turkey is close to $14 \%$, and the unofficial rates are much higher given those who work in the black market. However, there are additional factors one needs to take into consideration. Labor participation is only $50.8 \%$ with a reserve army of the unemployed who have stopped their job

\footnotetext{
${ }^{5}$ (Evrensel, 2020)

${ }^{6}$ https: / /tr.euronews.com/2020/12/07/turkiye-de-iscilerin-nekadari-asgari-ucretle-calisiyor-sendikalar-2020-tespit-komisyonu

${ }^{7}$ https:/ / t24.com.tr/haber/turkiye-de-191-bin-916-kisi-milyoner16-5-milyon-kisi-aclik-sinirinin-altinda, 850298
} 
search because they have lost their hopes to find a gainful employment. The creation of a New Deal style job guarantee program, which provides jobs to anyone who has been involuntarily unemployed and is willing to work, could instead find gainful employment rather than collecting welfare.

ELR has been successfully implemented throughout the world with overwhelmingly positive results (Tcherneva, 2018):

1. Large-scale employment programs: Plan Jefes y Jefas, Argentina. National Rural Employment Guarantee Act (NREGA), India. New Deal, the United States.

2. Youth employment guarantees: Youth Incentive Entitlement Pilot Projects (YIEPP), the United States. Future Jobs Fund, the United Kingdom.

3. Small direct employment programs, the United States: Localized programs in distressed communities that serve the homeless and ex-convicts.

The most recent example to an ELR program, which can serve as a blueprint for Turkey is Argentina (Tcherneva and Wray 2005). The author also believes the Argentine example to be the most suitable for Turkey as a start, given its population size, economic volatility, and persistent unemployment. Following the economic crisis in 2001, Argentina created the Plan Jefes y Jefas, which is similar to Minsky's ELR program and guaranteed a job for poor heads of households. This program is on a voluntary basis, which provides four hours of community work for the unemployed heads of households at the minimum hourly wage. It has provided two million jobs in less than a year with $13 \%$ of the labor forces showing up to work. Jefes had a considerable impact on the poor, especially on the disenfranchised minorities and women. The program had a countercyclical impact on Argentina's economy by stabilizing output, prices, and currency. The overall cost was less than $1 \%$ of GDP and launched 8-12\% annual GDP growth from 2003-2007. Later, this dipped to 5\%. Furthermore, it had moved the government budget into surplus due to the generation of large number of taxable incomes. Multiplier impact was 2.57, which means for every dollar invested into the program, 2.57 USD of GDP were generated. Many program participants subsequently transitioned into private sector jobs. This program was created as an emergency measure, á la depression economics, as a result of public protests in Argentina, and it was up and running in a few months similar to the New Deal in the US, offering part- and full-time jobs to two million people who showed up to work, which constitute $13 \%$ of the labor force. At that time, Argentina had $25 \%$ unemployment, a figure quite close to the current unemployment levels in Turkey.
One advantage is that an ELR program targets those at the very bottom of the labor market, i.e., those who are fired first and employed last, and are unable to gainful employment. This would be a particularly attractive 1.2 million technically "unemployed" in Turkey, who are no longer counted in official unemployment statistics because they have been unemployed for so long that they are not even looking for a job any longer. By setting a wage and benefits package, the ELR program sets up a floor at which the wages cannot go any further below and sets the minimum standards that the private sector can offer. This is not to mean that such wages offered by the ELR would have a crowding out effect, which effectively moves disposable labor employed in the private sector into the ELR scheme. The program ensures that the currently idle labor which could not find gainful employment neither in public not private sector, are employed under the ELR scheme. A second benefit is that by providing ELR to the unemployed in Turkey, the government not only minimizes the social costs of the consequences associated with unemployment, foregone production, and poverty, but also prevents social and moral fabric.

\section{Applying ELR in Practice in Turkey: A Few Thoughts}

While each country has its own challenges and dynamics, Turkey, as a developing country, faces challenges similar to other developing countries, such as Argentina and India, which have implemented ELR policies. First immediate benefit of the ELR is that its main program participants come from the chronically unemployed who have been unable to participate in the labor market. This includes both men and women who are readily employable or those who could be equipped with proper training while they are on the ELR program and could transition into private sector employment. These people certainly include women who have been cut off from the labor market and remained "unemployable," either because they do not have sufficient professional formation or they have been occupied with child-rearing or homemaking responsibilities. An ELR in Turkey would particularly empower the women as they would not only gain their economic self-sufficiency but also re-introduce them to the labor force by making them employable through their participation and endowing them with formative trainings as part of the ELR. Given the exceedingly low female labor participation where only $34.6 \%$ of women are engaged in gainful employment, a job guarantee will provide a boost to the economic productivity of women as they will be earning taxable income and receive recognized training, 
and they would be able to use in the public and private sector, as well as enhancing their presence as workers and become visible actors as economic agents. This requires a re-definition of women in the society as the paternalistic definition of women's place in the society and labor force would be overridden, giving the women the respect and dignity as they become more self-sufficient in their attainment of paid employment. Moreover, a guaranteed job opportunity would liberate women from a semi-compelled cycle of domesticity and economic inactivity due to lack of job opportunities and the normative expectations about their role in the society.

Second, the enacted programs such as the New Deal in the US in the 1930s and Jefes in Argentina in the 2000s have a transformative effect on many facets of the society (Tcherneva and Wray, 2005; Wray, 1998; 2012). It empowers the potential workers, who are willing to work and earn a taxable income. This would also have a positive multiplier effect to the economy through increased purchasing power and spending as well as boosting the state finances in Turkey as such wages would be taxable. It helps the firms because they would now be able to find employable labor who have a track record of continuous and gainful employment and received vocational training during their time in ELR, which will in return reduce the amount of training costs by the firms. This would be particularly welcome to those firms, which do not have sufficient resources to be able to train their own staff on the job and rely on the prior knowledge of their workers. It strengthens the communities to fill their social services gap, which otherwise would be ill-equipped to be able to bear the cost of coordinating and hiring such facilities on their own. This would be particularly welcome in less privileged regions in Turkey, who are net contributors to the state budget and, for most part, rely on transfers from the central government to finance their social work and welfare programs. The full employment brought forward by the ELR would ensure that the effective consumer demand for goods and services would be more widely distributed in the economy. Most importantly, this boosts the overall economy on multiple fronts. It would set a floor to wages and benefits (i.e. social security) in the Turkish economy, where each worker would be guaranteed a job and steady income with benefits. An additional benefit is that the already meagre spending on welfare, which would have otherwise been paid out to the unemployed, could be used in the financing of the ELR program as well as preventing the huge costs of the forgone productive capacity aside from the social cost of dealing with the consequences such crime, poverty, and social alienation (Wray, 2012). The workers instead become direct contributors to the state finances by being tax-paying workers as opposed to being welfare-beneficiaries of the unemployment insurance.

My proposal for Turkey is that the implementation of an ELR program should not only be limited to decentralized grassroots projects as in Jefes program in Argentina. The author also proposes to go further and suggests that the ELR program's scope should be widened to a New Deal style jobs program that have been put in place during the Great Depression in the 1930s, while considering the unique composition of the unemployed in Turkey. While there are millions of people who lack the job experience and professional skills desired by the job market, one must also consider the fact that there are several other sets of the unemployed, which we should consider. On one side, we also have the semi-qualified graduates, who finish their schooling from secondary and higher education institutes, albeit without the employable and desired skillset (IT, foreign language skills, technical qualifications, etc.) in the job market. Even when they have the skillset, it is quite common that they could not find an employment opportunity because they have not had any prior professional experience, which causes an employment "catch-22." The widening scope of ELR to a New Deal style jobs program would ensure that a larger reserve pool of the unemployed are put to work in order to increase labor participation, particularly for the disadvantaged (i.e., women, longer-term unemployed, people without formal and/or sufficient qualifications). Enabling these people to work is preferable to transfer payments in the forms of welfare. This would also prevent them from remaining idle and being further discouraged to seek work.

\section{Who?}

Experience in other countries has shown that most people who go to JG programs have previously been socially marginalized, and they have low skills. This includes people with a low track record of, often precarious, employment history who have had no tangible real opportunities in life. This is an opportunity for them to develop their human capital and to improve their capacity.

\section{Target Areas?}

At the first stage, it would be sensible to focus on the areas where the unemployment level is particularly high. My initial proposal is to begin in the areas whose unemployment is above $20 \%$. Turkey has experienced rapid urbanization during the last forty years in all seven regions of Turkey, where $75 \%$ of 
the population live in urban areas. This has resulted in depopulation in large swathes of the country with ever-decreasing employment prospects. The program could first be started in rural Anatolia and gradually be expanded to the urban areas with high unemployment.

Those without any skills or job experience are the most vulnerable in the job market, which include stay-at-home women who do not have an employment history as well as low-skilled unemployed heads of households who have been made redundant. These programs are certainly important for those who do not have the competitive skillset in order to participate in the current labor market, however, they have the willingness to work. Vocational training can be provided in addition to the job guarantee, which will help the participant to transition to the private sector with the desired skillset. My non-exhaustive list of such programs includes the following:

\section{a. Agro-Cooperatives}

The Anatolian heartland has plots of land which remain idle. They are located primarily in Central, Eastern, and Southeastern Turkey. These plots could be assigned to the willing ELR participants, who could use the previously disused farmland for raising crops for own consumption and outside sale. The ELR program could jumpstart this project by the provision of the seeds, fertilizer, and farm equipment.

\section{b. Social services 8}

The outbreak of COVID-19 has underlined the insufficient amount of personnel in the healthcare and primary care facilities at the community health clinics and hospitals. With the required on-the-job and formal training to the ELR participants, the lack of manpower could be sourced from this pool. The social services could also be enhanced in rural and metropolitan areas alike, which routinely lack access to libraries, fine arts (i.e., museums, exposition centers), retirement homes, community clinics, facilities for the disabled, personnel for public schools, day care services, soup kitchens, and food banks.

Turkey is particularly prone to natural disasters, especially earthquakes and forest fires. In the light of such events, qualified people for environmental clean-up and maintenance efforts also come to the fore given that trained disaster relief teams, and equipment are also in short supply, and ELR programs could be geared to address this shortcoming.

\footnotetext{
${ }^{8}$ One must note that it is primarily the local municipalities, and not the national government, are the main providers of social services in Turkey to the needs of the poor and disadvantaged.
}

\section{c. Schooling}

An acute program in Turkey is the vast group of trained primary- and secondary-school teachers who are unable to find a job after having finished their teachers' education neither at the private schools due to lack of demand nor at the public schools because they are not assigned a post. Their numbers have reached 700,000 as per January 2020. This is a contrast where there is a vast army of unemployed teachers even though there is a lack of 155,000 open teaching posts ready to be filled ${ }^{9}$ Ironically, the rural parts of Anatolia, particularly schools located in Eastern, Southeastern, Black Sea, and Central Anatolian regions suffer from lack of sufficient teachers.

\section{d. Infrastructure programs}

Work Project Administration (WPA) and the Civil Conservation Corp (CCC) in the US would be the most notable antecedents to an ELR program in Turkey. This will help to employ millions of job seekers in order to carry out public works projects for the construction of public roads and infrastructure ${ }^{10}$ which are in dire need of repair and upkeep. It would not only be the unemployed workers who would be put to use in such projects. There are tens of thousands of unemployed university graduates with degrees in natural sciences, urban planning, and engineering, whose skills would be put to use in such projects.

\section{e. Fine arts}

Employing the unemployed musicians, artists, writers, actors, and directors in arts, drama, media, and literacy projects for public outreach programs could also complement this program. This would be particularly beneficial to these groups as they are the hardest hit due to the COVID-19 outbreak. Theater and music groups can tour throughout Turkey and give performances. Archeological investigations under the ELR program could help to uncover the rich archeological heritage buried under the soil in Anatolia and take the development of professional archeology a step further in Turkey.

\footnotetext{
${ }^{9}$ https://www.mebpersonel.com/sozlesmeliogretmenler/atanamayan-ogretmen-sayisi-55-ulke-sayisini-gectiogretmen.php.

${ }^{10}$ For the last two decades, the public works constructions have been mainly done through public-private partnerships, where the government has promised 'cost-plus' revenue guarantees to the private companies, which construct and operate the public sector investments and have been widely criticized as being open to graft allegations.
} 
How long?

In order to ensure that the ELR jobs would be perceived as real and tangible jobs, my proposal for Turkey that the ELR would not be limited to a few weeks or months. Successful implementation of ELR in other countries have shown that it is sensible to design the ELR jobs to have a timespan of at least three years to ensure the buy-in from the workers and reap the benefits of the program.

The ELR would have microeconomic advantages for the workers and the community as well as macroeconomic advantages for the overall economy. First advantage is the provision of a fair wage and working conditions for the workers. By providing a fair wage for a guaranteed job, the worker would no longer be living under the shadow of precariousness and the imminent possibility that they could lose their job and not be able to find another one easily. $44 \%$ of the Turkish labor force works at a minimum wage of TRL 2,825 (USD 331 in August 2021 rates), which is below the poverty level. Given the high level of unemployment, it is rather convenient to dismiss and replace the workers given the number of unemployed people who are willing to take up a job at almost any wage. Losing a job also causes substantial mental stress, given that finding a new job is challenging and the welfare benefits pertaining to unemployment are rather limited compared to what one might find in Western Europe. Guaranteeing a job with fair wages would eliminate the financial insecurity, which precedes their unemployment. Second, the employment expands and improves the social networks of the workers, given their exposure to other. Including those who are unemployed into the formal work force would introduce them to social networks, which they were unable to utilize before. Third, the ELR jobs endow the participants with social and technical skills, which would help them with their future employment prospects. This would be complemented with on-the-job training as well as any additional formal training they would receive during the course of their employment. Fourth, having the guarantee of gainful employment would reduce the burden on the mental health of the workers, who would be comforted by the fact that they would be able to find work at will so long as they are willing to work.

On the macroeconomic side, the first advantage is the reduction of income inequality. Having a guaranteed gainful employment would increase the disposable income and spending, which would, in return, reduce the income disparities between those with and without employment. Second, the wage offered as part of ELR would also act as a minimum standard for the private sector in particular, and for the entire economy in general. Having an effective minimum wage as the ELR wage would help to support the effective demand in the economy. Third, the ELR program would improve the human capital and productivity. The ELR would allow people to climb up the employment ladder and increase their employable skills, which is particularly beneficial to those who were not gainfully employed before. In an economic downturn, it is usually the low-income precarious workers who were last to be hired that are first to be fired, which exacerbates their plight. Moreover, job guarantees are much more than programs for securing the right to work and stabilizing the business: they are also policies for social change and transformation (Tcherneva, 2008a). Fourth, an introduction of ELR would have a minimal impact on inflation because in part the overall productivity in the economy is improved, given that the labor of those who were not previously contributing are now included in the labor force. Through a prudent design of a full employment factor, potential inflation effects can be mitigated. This helps the economy to use the latent capacity, which was previously not utilized. Additionally, their wage earnings have a multiplier effect as the workers have a higher disposable income for their consumption due to their employment as opposed to being on the dole, or worse, not having any income. Fifth, this ELR would work with countercyclical automatic stabilization effect, which mean that the participants to the ELR program would increase in an economic downturn and decrease in an upturn. Participants would be endowed with the necessary skills and the confidence which they would be able to utilize if they would like to switch to the private sector.

\section{Financing the ELR Program}

The critics to the ELR program implemented around the world have addressed their concerns to the affordability of the program. The conventional thinking is that the government depends on two sources of funding: It can borrow savings from the people or it can raise the taxes. If the government wants to collect more money by taxing, it can raise additional funds by borrowing from the savers. The bottom line is the government must come up with the money before it can spend. As the monopoly issuer of the fiat currency, MMT argues that the government spends first and then taxes and borrows. This is completely opposite of the conventional thinking: Spending comes before taxing and borrowing, and when the government wants to spend, it simply spends money into existence (Mosler, 2013). The amount required by the ELR program can simply be financed by the government by deficit spending given that it is the 
monopoly issuer of the Turkish Lira. The government can afford to purchase whatever is on sale, including labor, and it can never "run out of money."

MMT argues that the governments can maintain to avoid inflation and promote price stability along with full employment by creating a nondiscretionary automatic stabilizer. This is conducted by the job guarantee program acting as a shock absorber in the economy to hire all redundant labor due to involuntary unemployment. The way it works is as follows: The Turkish government announces a wage and benefits package to the job seekers who are looking for work but could not find suitable opportunities. Then, the government commits to funding jobs gearing toward increasing public welfare. This creates a public option in the labor market with the government fixing an hourly wage and allowing the quantity of workers hired into the program to float (Kelton, 2020). The government gives an open-ended commitment and becomes a market maker for the labor of the redundant workers by setting the price to hire them in exchange for performing public service work. By doing so, involuntary unemployment disappears because anyone looking for paid employment has guaranteed access to a remunerated job set by the government. Furthermore, the size of the program can be reduced and increased during the boom and bust cycles in order to insulate the economy by using a discretionary policy without throwing millions into unemployment ${ }^{11}$ This makes the program a powerful automatic stabilizer because it maintains incomes and keeps people employed during the business cycle, therefore reducing the duration and severity of recessions. MMT approach to combat involuntary unemployment is not by leaving some people always unemployed in order to tame inflation or maintain the "natural rate" of unemployment, but by fully eliminating it. The ELR program helps to stabilize inflation by anchoring a key price in the economy-the price paid to workers by the government becomes a benchmark to all employers in the public and private sector.

With its own currency operating in a floating exchange regime, the financing of an ELR program would not be a challenge in terms of affordability so long as there are workers ready to work at the ELR wage and there is a monetary sovereign who can finance it (Wray, 2012). Here, the wage level should be set so that it would act as a floor for wages at which all those willing to work would be employed at this wage. An ELR in Turkey would have a reserve pool of possible workers of 11.7 million people with the current unemployment level in Turkey. This figure not only includes those who are unemployed, but also those who are no longer included in the statistics because they have given up the

\footnotetext{
$11_{\mathrm{ibid}, \text { p. }} 251$
}

hope of finding work, as well as those in unpaid labor and forced redundancies and shorter worker due to COVID-19 pandemic. As a rough estimate, the author still expects at least half of the people to remain in the reserve pool in a potential economic upswing.

Governments shy away from pursuing full employment because they believe that they cannot hire all the employed or they are bound by political rules on public deficit and debt like in the Eurozone (Ehnts, 2016). Given that Turkey maintains its monetary sovereignty, it can pursue a full-employment policy through a job guarantee program. This is achievable because even as a developing country, a sovereign currency allows government to buy anything for sale in the domestic currency, including all unemployed labor (Wray, 2012). The government can certainly afford to hire the labor and to mitigate the inflationary pressure due to excessive government spending; it must design the job guarantee program such that the program does not trigger a rapid increase in the inflation. A problem remains, however, the part of public debt denominated in foreign currency. It is therefore ideal that the volatility of the Turkish Lira should be reduced in order to validate its creditability.

The cost of an ELR program is certainly contingent upon the expansiveness of the whole scheme. However, when we look at the total government spending on Jefes in Argentina, this was equal to about 1\% of GDP with nearly two million participants from a population of thirty-seven million people, which amounts to roughly $5 \%$ of the population (Tcherneva and Wray, 2005). While US spends $1 \%$ of GDP on anti-poverty social assistance, and France and the UK spend 3-4\% of GDP on such programs (Neubourg, Castonguay, and Roelen, 2005). When we look at the social spending as a share of GDP, US, France, and UK spend 18.7\%, 31\%, 20.6\% of their GDP respectively ${ }^{12}$ The figure in Turkey is significantly lower, spending $12 \%{ }^{13}$ of its GDP on social spending. An introduction of full-employment program would certainly reduce the number of people who are on social assistance and turn the participants into net economic contributors with their labor and taxable income.

\section{Conclusion}

The ELR program is a plausible alternative to the crippling unemployment problem in Turkey. In addition to a few project ideas above, there are countless works where the unemployed could be put to use. As mentioned above, similar ELR programs in India, Argentina, US, and Canada have used agriculture, environmental

\footnotetext{
${ }^{12}$ https://www.statista.com/chart/24050/social-spending-bycountry/

${ }^{13}$ The number of people seeking economic assistance from the state is likely to increase due to the Covid-19 pandemic.
} 
clean-up, infrastructure investment, reforestation, and schooling. Given the regional needs and the skillset of the unemployed, a further diversified set of projects could be put forward. Wray (1998) has argued that the US can use many low-income housing restoration engineers, environmental safety monitors, and public-school classroom assistants . Mitchell (1998) has advocated for large-scale urban renewal, river valley erosion program, and dune stabilization in Australia. Antonopoulos et al. (2010) have noted that social sector investments, in home-based care or early childhood education for instance, can create 1.5 times as many jobs as investments in the "green" economy and twice the number of jobs that would be created from infrastructure investment.

The decision lies with the Turkish society who has to make a societal choice as a whole for a macroadjustment. The author believes that they have three alternatives in front. They will either bear living with unemployment and its consequences, such as the risk of losing social networks, consequences for the families, and the loss of talent and capacity as well as wasting the use of latent labor capacity. Second is that the labor force will largely move to a state of precarity with the widespread adoption of the gig economy. Third is to ensure that there is a decent and well-paying job which reduces social alienation and income inequalities while contributing to the social provisioning. There are successful examples in front of Turkey such as the Jefes y Jefas program in Argentina, India's Rural Employment Guarantee scheme, as well Canada's Community Employment Innovation Program in the recent years, as well as the WPA in the US in the 1930s. These programs have shown that continued participation in ELR have contributed to the improvement of social capital and richer social networks in addition to the improvement of the quality of work after the ELR program completion, thanks to the skills and experience earned during the course of the program. Subsequently, the poverty and financial stress on the society is reduced. The community and social economy capacity are increased through the injection of additional workers in the social sector.

The dividends of an ELR are multifold. There is a direct correlation between widespread unemployment and increase in crime rates, poverty, and social alienation. By providing a job guarantee, the government would not only be generating a tax source by creating means for employment for the unemployed while investing in the public works and infrastructure, but also gain the additional benefit of creating a multiplier effect because of the wages earned by the ELR participants increase the effective aggregate demand in the economy while reducing the poverty and social alienation. ELR would also help to bridge the gap in female unemployment. The role played by the job guarantee and ELR program on female wages and empowerment has been documented in a similar program enacted in India's Rural Employment Guarantee program and Argentina's Jefes (Ghosh, 2014; Tcherneva and Wray, 2005). Evidence has shown that the ELR programs are particularly good for rural women as they are drawn at a much greater extent than men. This would have not only helped to reduce the female labor participation which is particularly low in Turkey, and even more so in the rural areas, but also ensure that the female wages increase and reduce the gender wage gap. The application of ELR should be guided by the consideration of the real problem, that is to provide employment for everyone, which requires political willpower and a societal choice.

\section{BIBLIOGRAPHY}

Antonopoulos, R., Kim, K., Masterson, T., Zacharias, A. (2010). Why President Obama Should Care About "Care": An Effective and Equitable Investment Strategy for Job Creation. Public Policy Brief (108).

Bora, T., Erdoğan, N. (2017). Cüppenin, k1lıcın ve kalemin mahcup yoksulları. In T. Bora, A. Bora, N. Erdoğan, İ. Üstün, Boşuna mı Okuduk? Türkiye'de Beyaz Yakalı İşsizliği (pp. 13-15). İstanbul: İletişim Yayınları.

Castel, R. (2008). Die Metamorphosen der sozialen Frage. (A. Pfeuffer, Trans.) Konstanz: UVK Universitätsverlag.

Ehnts, D. (2016). Modern Monetary Theory and European Macroeconomics. Basingstoke, UK: Routledge.

Ehnts, D., and Höfgen, M. (2019). The Job Guarantee: Full Employment, Price Stability, and Social Progress. Society Register, 3(2), 49-65.

Evrensel. (2020, June 20). DİSK-AR: Kovid-19 döneminde geniş tanımlı kadın işsizlik oranı yüzde 45,3 oldu. Retrieved January 8, 2021, from Evrensel: https:/ / www.evrensel.net/haber/407575/disk-arkovid-19-doneminde-genis-tanimli-kadin-issizlikorani-yuzde-45-3-

Forstater, M. (1999). Public employment and economic flexibility: The job opportunity approach to full employment. Levy Economics Institute. Annandale-on-Hudson, NY: Bard College.

- Full employment policies must consider effective demand and structural and technological change: a prime point of Pasinetti's political economy. 
In P. Davidson, A Post Keynesian Perspective on 21st Century Economic Problems (pp. 195-215). Cheltenham, UK: Edward Elgar.

Ghosh, J. (2014). Can Employment Schemes Work? In D. B. Papadimitriou (Ed.) Contributions to Economic Theory, Policy, Development and finance: Essays in Honour of an J. A. Kregel. New York: Palgrave Macmillan.

Harvey, P. (1989). Securing the Right to Employment. Princeton, NJ: Princeton University Press.

Kelton, S. (2020). The Deficit Myth: Modern Monetary Theory and How to Build a Better Economy. London: John Murray.

Keynes, J. M. (1936 [1964]). The General Theory of Employment, Interest and Money. New York: Harcourt Brace World, Inc.

Keynes, J. M. (1972). Essays in Persuasion. In D. Moggridge (Ed.), The Collected Writings of John Maynard Keynes (Vol. 9, pp. 90-92). London and Basingstoke.

Keynes, J. M. (1980). Activities 1940-46. Shaping the Post-War World: Employment and Commodities (Vol. XXVII of Collected Works). (D. Moggridge, Ed.) London, UK: Macmillan.

Kregel, J. A. (1999). Currency Stabilization through Full Employment: Can EMU Combine Price Stability with Employment and Income Growth. Eastern Economic Journal(1), 35-48.

Kregel, J. A. (2008). The Continuing Policy Relevance of Keynes's General Theory. In M. Forstater, L. R. Wray (Eds.), Keynes for the 21st century: The Continuing Relevance of the General Theory. London: Palgrave Macmillan.

Lipietz, A. (2001). The Fortunes and Misfortunes of Post-Fordism. In R. Albritton, et al, Phases of Capitalist Development: Booms, Crisis and Globalizations (pp. 17-36). Hampshire: Palgrave.

Lowe, A. (1988). Has Freedom a Future? New York: Praeger.

Minsky, H. P. (1986). Stabilizing an Unstable Economy. New Haven, CT: Yale University Press.

Minsky, H. P. (n.d.). The Role of Employment Policy. In M. S. Gordon, Poverty in America. San Francisco, CA: Chandler Publishing Company.
Mitchell, W. F. (1998, June). The Buffer Stock Employment Model and the NAIRU: The Path to Full Employment. Journal of Economic Issues, 32, 547-568.

Mitchell, W., Muysken, J. (2008). Full Employment Abandoned: Shifting Sands and Policy Failures. London: Edward Elgar.

Mosler, W. (1997-98). Full Employment and Price Stability. Journal of Post Keynesian Economics, 20(2), 167-182.

Mosler, W. (2013). Soft Currency Economics II. Christiansted: CreateSpace Independent Publishing Platform.

Negt, O. (2010). Der politische Mensch. Goettingen: Steidl Verlag.

Neubourg, C., Castonguay, J., and Roelen, K. (2005). Social Safety Nets and Targeted Social Assistance: Lessons from the European Experience. Retrieved 01 27, 2021, from World Bank Briefings: http://www1.worldbank.org/sp/safetynets/ Training_Events/OECD_3-05/EU_Briefing_Book.pdf

Papadimitriou, D. B. (2012, January 5). Need Jobs? Call on Government. Retrieved January 23, 2021, from Los Angeles Times.

Pasinetti, L. L. (1993). Structural Economic Dynamics. Cambridge: Cambridge University Press.

Rifkin, J. (2007). Das Ende der Arbeit. (T. Steiner, H. Schickert, Trans.) Frankfurt am Main: Fischer Verlag.

Rogers, C. (2010). The principle of effective demand: the key to understanding the General Theory. In R. W. Dimand, R. A. Mundell, A. Vercelli (Eds.), Keynes's General Theory After Seventy Years (IEA Conference ed., Vol. 147). London and Basingstoke: Palgrave Macmillan.

Tcherneva, P. (2008). Keynes's Approach to Full Employment: Aggregate or Targeted Demand? The Levy Economics Institute of Bard College, Annandaleon-Hudson, NY.

- (2008). The Promise of Fiscal Policy: Full Employment, Stability and Equity. Kansas City: University of Missouri-Kansas City. 
- (2012). Permanent On-The-Spot Job Creation - The Missing Keynes Plan for Full Employment and Economic Transformation. Review of Social Economy, $70(1), 57-80$.

- (2018). The Job Guarantee: Design, Jobs, Implementation. Annandale-on-Hudson, NY: Levy Economics Institute of Bard College.

-. (2020). The Case for a Job Guarantee. Medford, MA: Polity Press. Tcherneva, P., and Wray, L. R. (2005). Gender and the Job Guarantee: The Impact of Argentina's Jefes program on female heads of poor households. Center for Full Employment and Price Stability. Center for Full Employment and Price Stability.

Vickrey, W. (2004). Chock-full employment without increased inflation: A proposal for marketable markup warrants. In M. Forstater, and P. Tcherneva, Full employment, and price stability. Cheltenham: Edward Elgar.

Wacquant, L. (2007). Die Verallgemeinerung der Lohnunsicherheit in Amerika. Konstanz: UVK Verlag.

Wray, L. R. (1998). Understanding Modern Money: The Key to Full Employment and Price Stability. Northampton, MA: Edward Elgar.

-. (2012). Modern Money Theory: A Primer on Macroeconomic for Sovereign Monetary Systems. New York: Palgrave Macmillan. 